\title{
THE USE OF STATIONARY TESTS FOR ANALYSIS OF MONITORED RESIDUAL PROCESSES
}

\section{WYKORZYSTANIE TESTÓW STACJONARNOŚCI DO ANALIZY MONITOROWANYCH PROCESÓW RESZTKOWYCH*}

\begin{abstract}
Sustaining high operational efficiency of a machine park requires the use of state-of-art solutions that support both monitoring of residual processes and performing thorough analysis of thereby collected data. What meets the needs of entrepreneurs who strive for high reliability of technological infrastructure is a modern approach to maintenance prediction. The literature of the subject offers numerous studies presenting the use of various statistical models for time series prediction. The objective of this paper is to verify whether tests used in econometrics such as the augmented Dickey-Fuller test and the Kwiatkowski-Phillips-Schmidt-Shin test are suitable for failure prediction. The simulations were performed for one diagnostic parameter, i.e. temperature.
\end{abstract}

Keywords: failure prediction, maintenance, stationary tests, ADF, KPSS.

\begin{abstract}
Utrzymanie wysokiego poziomu efektywności eksploatacyjnej parku maszynowego wymaga stosowania nowoczesnych rozwiazań wspierajacych monitorowanie procesów resztkowych i poddawania szczegółowej analizie uzyskanych w ten sposób informacji. Naprzeciw oczekiwaniom przedsiębiorców dotyczacych utrzymywania wysokiego poziomu niezawodności infrastruktury technicznej wychodzi nowoczesne podejście w obszarze gospodarki remontowo-konserwacyjnej, jakim jest predyktywne utrzymanie ruchu. W literaturze przedmiotu wielokrotnie prezentowano wykorzystanie różnych modeli statystycznych pozwalających na prognozowanie wartości szeregów czasowych. Celem niniejszej pracy było sprawdzenie czy stosowany w ekonometrii rozszerzony test Dickeya-Fullera oraz test Kwiatkowskiego, Phillipsa, Schmidta i Shina moga zostać użyte do predykcji zdarzeń niepożądanych jakimi sq awarie. Symulację przeprowadzono dla wartości jednego parametru diagnostycznego jakim była temperatura.
\end{abstract}

Stowa kluczowe: predykcja awarii, utrzymanie ruchu, testy stacjonarności, ADF, KPSS.

\section{Introduction}

Meeting contractual obligations is one of the factors that affect operational efficiency of an enterprise. Hence, prompt delivery of a contracted quantity and quality of products is a key task of every company. On the one hand, the use of state-of-the-art manufacturing techniques and advanced production processes enables companies to meet contractual obligations; on the other, it poses problems regarding reliability of production equipment. Consequently, the actions supporting operations taken by a company's maintenance department (production equipment must be kept in constant operational efficiency by controlling technical condition of machines and devices) become increasingly significant. According to Legutko [1], operation is the whole of phenomena, processes and events that occur during the period of existence of a device, from the moment of its construction until its withdrawal from use. When used with respect to maintenance, the term "efficiency" is defined as a property of people or technical objects which determines whether they meet different requirements, e.g. in terms of reliability, economy or quality. Operational efficiency is a quotient of effects produced in a fixed time interval of duration of a given state of an operating object to the costs of achieving these effects. Increasing operational efficiency of machines via failure prediction and restoring full efficiency of a production system, ensures prompt completion of contractual obligations, which - in turn - means higher profits of the enterprise. This is of key importance given the strong competition between enterprises, where constant improvement of manufacturing systems, development of production technologies and production automation solutions are key to success.

The growing interest in predictive maintenance combined with the problem of unused data collected by systems monitoring machine park operations have inspired the present authors to undertake studies aimed at verification the effectiveness of failure prediction by stationary tests. Additionally, on detecting alarming symptoms, residual time of machinery operation was determined, too. Seasonal changes in ambient conditions can have a negative impact on values of observed state parameters and, thus, on the efficiency of predictions made using stationary tests. If this is the case, it is necessary to present assumptions concerning investigated signals (the effect of changes in ambient conditions on observation vector values). Since the simulation assumed maintaining constant ambient temperature conditions, its impact on non-stationarity was not taken into consideration.

\section{Effect of maintenance activities on operational ef- ficiency}

The observations made in the field of maintenance demonstrate that the dominant trend in most enterprises is to repair machines and devices only after failure, as a result of which the time for response actions exceeds the time for planned operations. This leads to a decrease in operational efficiency. In addition to this, poor condition

(*) Tekst artykułu w polskiej wersji językowej dostępny w elektronicznym wydaniu kwartalnika na stronie www.ein.org.pl 
of technical infrastructure leads to lower productivity generating additional losses. The actions taken to improve operational efficiency of enterprises should hence strive to eliminate waste in the form of inefficient work of both machines and maintenance staff. The indicators listed in the standard EN15341 [29] for determining maintenance services efficiency can be useful for verification of the efficiency of implemented improvements [23]. One of the most widely applied indicators is Overall Equipment Effectiveness (OEE) [1, 20, 19]. The considerations of ways of improving the functioning of maintenance and repair sector management also point to connections between operational efficiency level and its selected structure [20,23].

Maintenance operations are undertaken to:

- maintain specific quality of products/services,

- prolong as much as possible the operation life of production equipment,

- ensure conditions for safe operation of machines and devices,

- reduce production costs as much as possible by limiting production breaks.

The above actions can be implemented following determination of a machine or process state by physical quantities. The behaviour of machines or production processes is modelled by equations of state described by some functions $f(t), t \in T$, where the independent variable $t$ is a time variable, while $T$ is a time interval. The determination of state of a technical object is called diagnosing. Figure 1 shows schematically processes that occur in production and types of diagnosed working and accompanying processes.

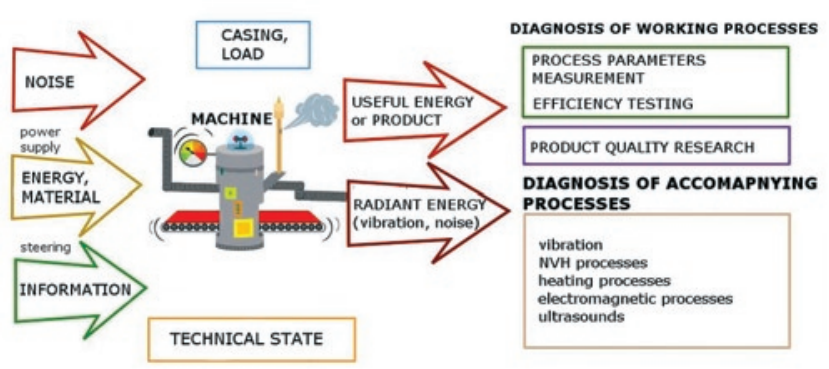

Fig. 1. Schematic representation of processes occurring in a machine and of methods for diagnosing working and accompanying processes [1]

What can occur in operational processes are random events caused, among others, by human error, impact of natural environment and operational environment. With wise modelling of random factors that affect behaviour of machines and production processes, we can increase operational efficiency of such objects $[18,24]$. It can therefore be claimed that maintenance is one of the key processes that have a direct impact on increasing operational efficiency.

The efficiency of a machine park depends on operations which provide a basis for_preventive maintenance. This means that decisions concerning machinery maintenance operations are taken based on technical and operational documentation. According to the predictive maintenance approach [4], the moment of maintenance operations in a production process should be scheduled based on machinery condition. For this reason, symptom monitoring, particularly in a non-invasive way, becomes more and more popular. The moments of machine maintenance operations are scheduled based on observation of residual processes using, among others, infrared cameras [37], vibroacoustic sensors [31] and pressure sensors [6]. Residual processes are thermal, frictional, electric and vibroacoustic (vibrations, noise, fluctuation of a working medium in the machine), and can often be a symptom or determinant of wear [5].

\section{Stationary processes and system reliability}

The behaviour of physical, economic and technical systems is usually described by mathematical models. First, based on historical data, values of structural parameters are determined, and then, following parametric identification, these models can be used to predict the behaviour of systems being described. The behaviour of machines and devices is often predicted by time series models. By predicting future values of system states, we can draw conclusions about a possibility of failure of machines and devices.

Time series can be divided into stationary and non-stationary (see e.g. $[2,11,7,27])$.

Definition 1. The time series $\left\{x_{t}\right\}_{t \in N_{0}}$ is said to be strict stationary if for every $m \in N$, any $t_{1}<t_{2}<\ldots<t_{m}$ and every $\tau \in N$ the joint distributions of the probability of $m$ elements of random sequences $x_{t_{1}}, x_{t_{2}}, \ldots, x_{t_{m}}$ and $x_{t_{1}+\tau}, x_{t_{2}+\tau}, \ldots, x_{t_{m}+\tau}$ are identical.

Therefore, for stationary time series, the statistical and dynamical properties for any time shift remain unchanged. Given the above, the mean and variance of the elements of the time series $\left\{x_{t}\right\}_{t \in N_{0}}$ are constant over time.

Definition 2. The time series $\left\{x_{t}\right\}_{t \in N_{0}}$ is said to be homogeneous non-stationary (homoscedastic) if, by separating a non-random component from the time series, we obtain a stationary series. Homogenously non-stationary series can contain among others a deterministic or stochastic trend; they can have a seasonal or periodic character. Following the application of a differential operator, such series can be reduced to stationary series $[2,11]$.

Definition 3. The time series $\left\{x_{t}\right\}_{t \in N_{0}}$ is said to be integrated of order $d$ (defined by $\left.\left\{x_{t}\right\}_{t \in N_{0}} \in I(d)\right)$ if the series $\left\{\Delta^{k} x_{t}\right\}_{t \geq k}$ for $0 \leq k<d$ is non-stationary, while the series $\left\{\Delta^{d} x_{t}\right\}_{t \geq d}$ is said to be stationary, where the differential operator $\Delta$ is defined as $\Delta x_{t}=x_{t}-x_{t-1}$, while $\Delta^{k+1} x_{t}=\Delta^{k} x_{t}-\Delta^{k} x_{t-1}$ for $k \in N$ (see e.g. [2, $11,15,27])$.

The stationarity of time series is most often investigated by the augmented Dickey-Fuller test [7], the Kwiatkowski-Phillips-SchmidtShin test [16], Philips-Perron test [28] (they are examples of unit root tests also known as stationary tests).

The above tests for time series analysis can be used to investigate reliability of systems and devices. If the results of classical unit root tests confirm the presence of stationarity (static and dynamic properties remain unchanged) and values of the system state are within a fixed range (belong to acceptable interval), then - given the lack of alarming symptoms - it is stated that the system behaves correctly. If it is found (based on the realization state system) that the quality of stationarity is not met, i.e. the system's behaviour contains a linear, polynomial trend (depending on integration degree), it is an alarming symptom. By using the differential operator $\Delta^{d}$ the non-stationary homoscedastic time series $\left\{x_{t}\right\}_{t \in N_{0}}$ can be reduced to the stationary series $\left\{\Delta^{d} x_{t}\right\}_{t \geq d}$ (for more information see $\left.[2,15,27]\right)$. The integration order $d$ defines the degree of a polynomial approximating for deterministic part in a time series (dependence between differentiation and polynomial trend is exhaustively discussed in $[15$, Section 2.4]). Next, using the least squares method, we determine a deterministic trend in the time series and then, based on prediction of behavior of the time series, we determine the expected time to exceeding acceptable values for a given system (alarming critical values) - residual operation time of a device. The subsequent section presents classi- 
cal stationary tests that are employed to determine the moment of taking a decision with respect to device maintenance operations.

\section{Stationary tests}

Maintenance can be achieved by repairing devices that restore efficiency of technical infrastructure. Maintenance dates are usually scheduled based on technical and operational documentation. The problem occurs when such actions are to be taken based on the real condition of a machine. To obtain information regarding the necessity of repair based on analysis of the diagnostic parameter, we used time series stationary tests.

Below, we present two classical stationary tests: ADF and KPSS.

To perform the augmented Dickey-Fuller test (ADF) [see e.g. 8, $11,15,27]$, it is necessary to consider the time series $\left\{x_{t}\right\}_{t \in N_{0}}$ with the state equation:

$$
\Delta x_{t}=\theta x_{t-1}+\sum_{i=1}^{k} \Delta x_{t-i}+\varepsilon_{t}
$$

where $\left\{\varepsilon_{t}\right\}_{t \in N}$ is a sequence of independent random variables with the normal distribution $N\left(0, \sigma^{2}\right)$. The order of autoregression $k \in N$ should be set such to eliminate correlations between the elements of the series $\left\{\varepsilon_{t}\right\}_{t \in N}$. Then, at the significance level $\alpha$, we construct a null hypothesis that the time series $\left\{x_{t}\right\}_{t \in N_{0}}$ is non-stationary (i.e. we take that $\theta=0$, therefore $\left\{x_{t}\right\}_{t \in N_{0}} \in I(d)$ and $\left.d \geq 1\right)$. As an alternative hypothesis, we take that the time series $\left\{x_{t}\right\}_{t \in N_{0}}$ is stationary (i.e. $\theta \in(-2,0)$, therefore $\left.\left\{x_{t}\right\}_{t \in N_{0}} \in I(0)\right)$. The test statistics:

$$
D F=\frac{\hat{\theta}}{S(\theta)}
$$

has a Dickey-Fuller distribution, where $\hat{\theta}$ is an estimator of the $\theta$ parameter, while $S(\theta)$ denotes the standard deviation of this parameter. The estimator of the $\theta$ parameter and standard deviation are determined by the least squares method. Based on the Dickey-Fuller distribution tables, we determine a critical value $D F^{*}$. If $D F^{*} \leq D F$, then at the significance level $\alpha$ there are no grounds to reject the null hypothesis, therefore the elements of the series $\left\{x_{t}\right\}_{t \in N_{0}}$ are integrated to one or higher (i.e. we take that the series $\left\{x_{t}\right\}_{t \in N_{0}}$ is non-stationary). If $D F<D F^{*}$, then on the significance level $\alpha$ we reject the working hypothesis in favour of an alternative hypothesis and take that the series $\left\{x_{t}\right\}_{t \in N_{0}}$ is stationary. If it is found that the series $\left\{x_{t}\right\}_{t \in N_{0}}$ is non-stationary, we additionally test the stationarity of the series $\left\{\Delta^{d} x_{t}\right\}_{t \geq d}$ for $\mathrm{d} \geq 1$ in order to determine the degree of a polynomial approximating deterministic part of the series $\left\{x_{t}\right\}_{t \in N_{0}}$.

The verification of time series stationarity can be done based on the Kwiatkowski-Phillips-Schmidt-Shin test [see e.g. 11, 14, 15, 27]
(KPSS test). Therefore, we must consider the series $\left\{x_{t}\right\}_{t \in N_{0}}$ with the state equation:

$$
x_{t}=\beta t+r_{t}+\varepsilon_{t}
$$

where $\left\{\varepsilon_{t}\right\}_{t \in N}$ is a sequence of independent random variables with the normal distribution $N\left(0, \sigma^{2}\right)$. The process $\left\{r_{t}\right\}_{t \in N_{0}}$ denotes a ran-
dom walk process

$$
r_{t}=r_{t-1}+v_{t}
$$

where $\left\{v_{t}\right\}_{t \in N}$ is a series of independent random variables with the normal distribution $N\left(0, \sigma_{v}^{2}\right)$. At the significance level $\alpha$ we construct the null hypothesis that the time series $\left\{x_{t}\right\}_{t \in N_{0}}$ is stationary (i.e. we take that $\sigma_{v}^{2}=0$, then the elements of the series $\left\{r_{t}\right\}_{t \in N_{0}}$ are constant and $\left.\left\{x_{t}\right\}_{t \in N_{0}} \in I(0)\right)$. As an alternative hypothesis, we take that the time series $\left\{x_{t}\right\}_{t \in N_{0}}$ is non-stationary (i.e. we take that $\sigma_{v}^{2}>0$, then $\left\{r_{t}\right\}_{t \in N_{0}}$ denotes a random walk process, which causes that the elements of the series $\left\{x_{t}\right\}_{t \in N_{0}}$ are created as the sum of elements of a stationary $\left\{\varepsilon_{t}\right\}_{t \in N}$ and non-stationary $\left\{r_{t}\right\}_{t \in N_{0}}$ series). For realization $\left\{x_{t}\right\}_{1 \leq t \leq n}$ we use the least squares method to estimate values of parameters of the model (3) and to determine the test statistics:

$$
\eta=\frac{\sum_{t=1}^{n} S_{t}^{2}}{n^{2} S^{2}(k)}
$$

where $\quad S_{t}=\sum_{i=1}^{t} \varepsilon_{i}, \quad S^{2}(k)=\frac{1}{n}\left(\sum_{i=1}^{n} \varepsilon_{i}^{2}+2 \sum_{s=1}^{k} w(s, k) \sum_{t=s+1}^{n} \varepsilon_{t} \varepsilon_{t-s}\right)$, weights $w(s, k)=1-\frac{s}{k+1}$ while $k$ denotes the order of delay. From the tables of the KPSS test, we take the limit value $\eta^{*}$. If $\eta<\eta^{*}$, then at the significance level $\alpha$ there is no ground for rejecting the null hypothesis, therefore it is taken that the elements of the time series $\left\{x_{t}\right\}_{t \in N_{0}}$ are integrated in order zero (we take that the series $\left\{x_{t}\right\}_{t \in N_{0}}$ is stationary). If $\eta \geq \eta^{*}$, then at the significance level $\alpha$, we reject the null hypothesis in favour of an alternative hypothesis and take that that the series $\left\{x_{t}\right\}_{t \in N_{0}}$ is non-stationary.

An algorithm of the proposed approach consisting in assessment of stationarity of time series of temperature is illustrated in Fig. 2. 


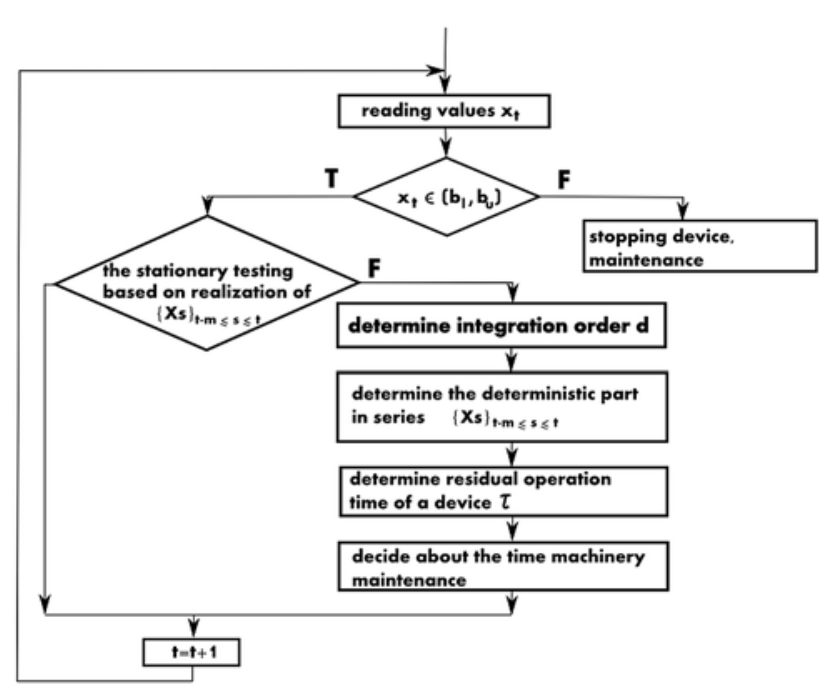

Fig. 2. Algorithm of the proposed approach consisting in assessment of stationarity of time series of temperature (prepared by the authors)

\section{Use of stationary tests for analysis of production machinery reliability}

Direct reading of device parameters allows us to find whether this device operates correctly (if the parameter value is within the acceptable limit) or not. The use of stationary tests during monitoring of machinery operation enables real-time verification of whether these machines operate correctly. If non-stationarity is detected in a time series by the least squares method, it is necessary to determine a trend in this time series, predicting in this way the behaviour and residual operation time of the device. The moment of determining non-stationarity in the time series is the moment of taking a decision about device maintenance (a maintenance operation date must be scheduled). If the remaining time for production realization does not exceed the residual operation time, then the production maintenance should be done following production process/contractual obligation; otherwise, it is necessary to schedule a maintenance date which does not exceed the residual operation time.

Below, we present the simulations of monitoring correct operation of production machinery by stationary testing. Tothis end, we used the ADF and KPSS tests. The simulations were performed using the MATLAB programme. The generated numerical values were to represent tem-

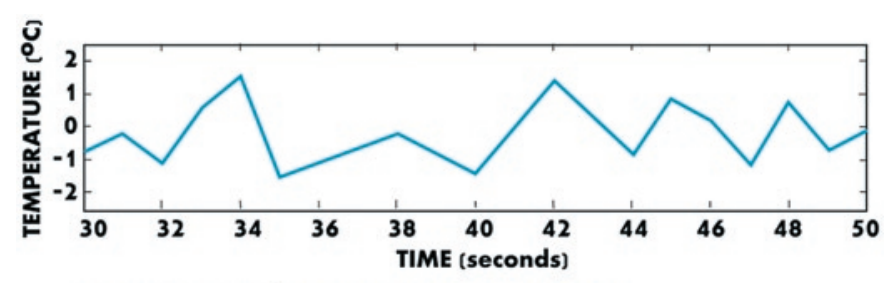

SENSOR NO. 1 NORMAL TEMPERATURE

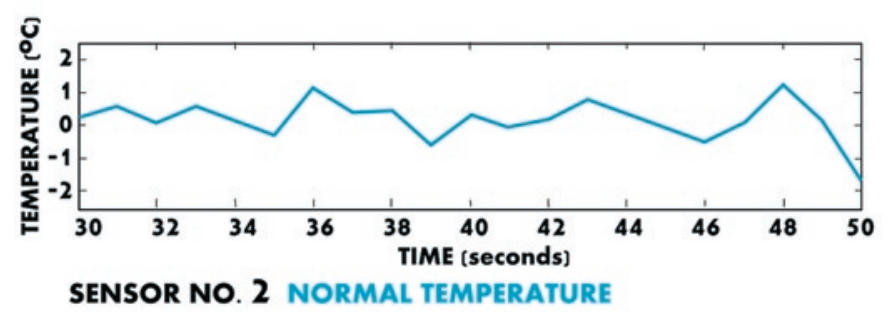

Fig. 3. MATLAB-generated diagrams showing temperatures recorded by two sensors (developed by the authors) perature values read from two sensors. These values were used to create dynamically diagrams for these sensors (Fig. 3).

The stationary dynamical testing was conducted based on $m$-element realization of the series $\left\{x_{s}\right\}_{t-20 \leq s \leq t}$ for $t \geq m$ (where $m=20$ ). If the observed values are within the acceptable interval $\left(b_{l}, b_{u}\right)$ and

the criterion of stationarity is satisfied, then it is concluded that the device is operating correctly. If the ADF test results pointed to nonstationarity, we used the least squares method to determine a trend in this time series $\left\{x_{s}\right\}_{t-20 \leq s \leq t}$. In addition, we determined the predicted

time to exceeding the critical temperature level, the acceptable interval of values being set to $\left(-20^{\circ} \mathrm{C}, 20^{\circ} \mathrm{C}\right)$. If the stationary analysis is performed based on short realizations of the time series and the device is placed in a room where atmospheric conditions does not affect its operation, the effect of environment can be omitted. Moreover, the selection of duration should be set adequately to the analyzed problem. Undoubtedly, a value from the previous observation moment is of higher informative significance than a value from the previous year, which is the so-called "data freshness problem".

Figure 3 shows the detection of process non-stationarity, residual time of correct operation of the device and the probability of the zero hypothesis. Based on the realization of $\left\{x_{s}\right\}_{60 \leq s \leq 80}$ for Sensor 1 by the least squares method, we also determined the state equation:

$$
x_{60+t}=5.35+0.492 t+\varepsilon_{t},
$$

where $\left\{\varepsilon_{t}\right\}_{t \in N}$ is a sequence of independent random variables with the normal distribution $N(0,0.83)$. Based on the results, we predicted subsequent temperature values on Sensor 1 using the equation:

$$
x_{80+t}=x_{80}+0.492 t+\varepsilon_{t},
$$

where $\left\{\varepsilon_{t}\right\}_{t \in N}$ is a sequence of independent random variables with the normal distribution $N(0,0.83)$ and $x_{80}=14.12$. The predicted temperature values are determined by the equation:

$$
\hat{x}_{80+t}=E x_{80+t}=x_{80}+0.492 t \text {. }
$$

The residual time of correct operation of the device is determined as:

$$
\tau=\min \left\{t \in N ; \hat{x}_{80+t} \notin(-20,20)\right\}=12 .
$$

Similar results were produced using the KPSS test during the monitoring of temperature reading on Sensor 1. The system user is notified about the exceeding of the critical/acceptable temperature limit by the information displayed under the diagram (Fig. 5). The simulated stationary test results demonstrate that both the ADF and KPSS test are effective methods for failure prediction based on the values of one residual process, i.e. temperature. Besides the ADF and KPSS tests, homogenous non-stationarity can also be investigated using such tests as the Philips-Perron test, Leybourn-McCabe test, Engle-Granger cointegration test, Johansen cointegration test, while non-homogeneous non-stationarity (heteroscedasticity, e.g. for vibration analysis) can be investigated by the Engle's ARCH test, BreuschPagan test, White's test, etc. 


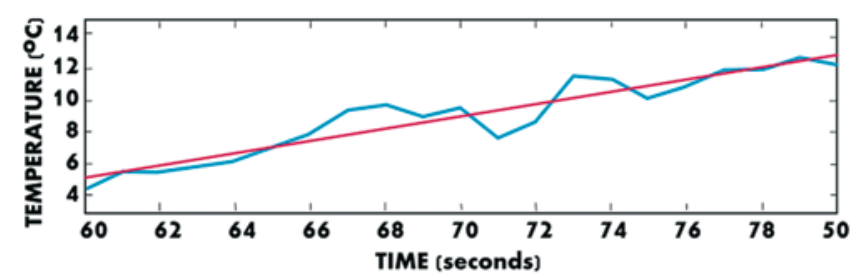

SENSOR NO. 1 Warning! The temperature will be exceeded in $12 \mathrm{sec}$.

Non-stationary process. ADF TEST $=0,99433$

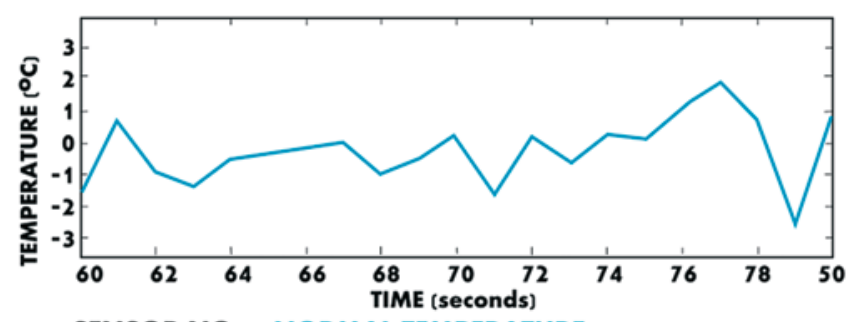

SENSOR NO. 2 NORMAL TEMPERATURE

Fig. 4 Notification about process non-stationarity generated due to changes in temperature (developed by the authors)

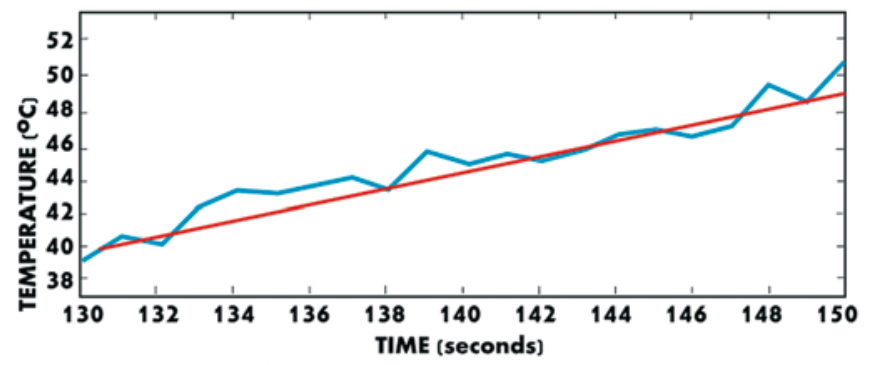

SENSOR NO. 1 Warning! The temperature is exceeded. Non-stationary process. ADF TEST $=0,99335$

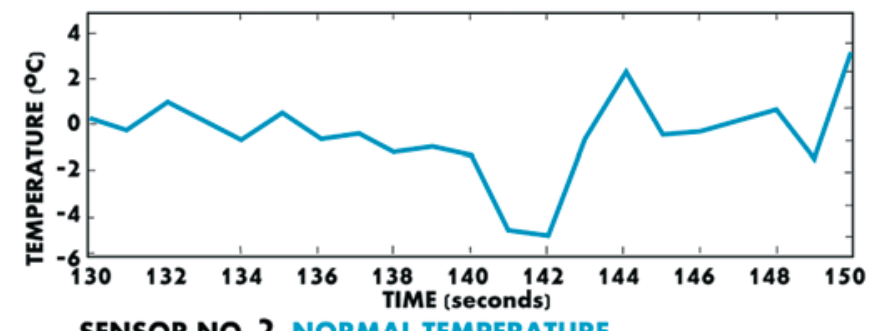

SENSOR NO. 2 NORMAL TEMPERATURE

Fig. 5 Notification that the temperature has been exceeded on Sensor 1 (prepared by the authors)

\section{References}

1. Antosz K, Stadnicka D. Evaluation measures of machine operation effectiveness in large enterprises: study results. Eksploatacja i Niezawodnosc - Maintenance and Reliability 2015; 17 (1): 107-117, http://dx.doi.org/10.17531/ein.2015.1.15.

2. Box G. E. P., Jenkins G.M. Analiza szeregów czasowych. Warszawa: PWN, 1983.

3. Burnos A. Efektywność utrzymania ruchu. Agro Przemysl 2012;2.

4. Carnero MC. Selection of diagnostic techniques and instrumentation in a predictive maintenance program. A case study. Decision Support Systems 2005; 38, http://dx.doi.org/10.1016/j.dss.2003.09.003.

5. Cempel Cz. Diagnostyka wibroakustyczna maszyn. Warszawa: PWN, 1989.

6. Cieślikowski B. Proces diagnostyki układu hydrauliki siłowej w mechanizmie obrotu pługa. Inzynieria Rolnicza $2009 ; 9$.

7. Chow G.C. Ekonometria. Warszawa: PWN, 1995.

8. Dickey D.A, Fuller W.A. Distributions of the estimators for autoregressive time series with a unit root. Journal of the American Statistical Association 1979; 74: 427-431.

9. Dutkowska B. Rosnąca rola systemów CMMS. http://www.utrzymanieruchu.pl/menu-gorne/artykul/article/rosnaca-rola-systemow-cmms/ (dostęp: 12.03.2015r.).

10. Doman M., Doman R. Ekonometryczne modelowanie dynamiki polskiego rynku finansowego. Poznań: Wydawnictwo Akademii Ekonomicznej w Poznaniu, 2004. 
11. Hamilton J.D. Time Series Analysis. Princeton: Princeton University Press, 1994.

12. Hetmańczyk M. Predykcyjne utrzymanie ruchu. Inzynieria \& Utrzymanie Ruchu Zakładow Przemyslowych 2015: 1, 60-64.

13. Ho T. The government spending and private consumption: a panel cointegration analysis. International Review of Economics \& Finance 2002; 10: 95-108, http://dx.doi.org/10.1016/S1059-0560(00)00073-3.

14. Komitet Inżynierii Produkcji PAN. Istota inżynierii produkcji. Warszawa: PAN, 2012.

15. Kozłowski E. Analiza i identyfikacja szeregów czasowych. http://www.kozlowski.pollub.pl/analiza_szeregow.pdf (dostęp: 12.06.2015r.).

16. Kwiatkowski D., Phillips P.C.B., Schmidt P., Shin Y. Testing the Null Hypothesis of Stationary Against the Alternative of a Unit Root. Journal of Econometrics 1992; 54: 159-178, http://dx.doi.org/10.1016/0304-4076(92)90104-Y.

17. Legutko S. Podstawy eksploatacji maszyn i urządzeń. Warszawa: Wydawnictwa Szkolne i Pedagogiczne, 2004.

18. Leszek W., Mazurkiewicz A., Trzos M. Projektowanie eksperymentalnych systemów badawczych w budowie i eksploatacji maszyn. Radom: Biblioteka Problemów Eksploatacji. Instytut Technologii Eksploatacji, 1999.

19. Ljungberg Õ. Measurement of overall equipment effectiveness as a basis for TPM activities. International Journal of Operations \& Production Management 2002: 18; 495-507, http://dx.doi.org/10.1108/01443579810206334

20. Loska a. exploitation assessment of selected technical objects using taxonomic methods. Eksploatacja i Niezawodnosc - Maintenance and Reliability 2013; 15 (1): 1-8.

21. Ludwig, B. Predicting the future: Have you considered using the Delphi methodology. Journal of Extension 2005; 6.

22. Mazurkiewicz D. Studium wybranych aspektów diagnostyki eksploatacyjnej transportu taśmowego. Politechnika Lubelska. Lublin, 2011.

23. Mączyński W., Nahirny T. Efektywność służb utrzymania ruchu jako składowa efektywności przedsiębiorstwa. Innowacje w zarządzaniu i inżynierii produkcji / red. R. Knosala. Opole: Oficyna Wydaw. Polskiego Towarzystwa Zarządzania Produkcją, 2012.

24. Młyńczak M. Metodyka badań eksploatacyjnych obiektów mechanicznych. Wrocław: Oficyna Wydawnicza Politechniki Wrocławskiej, 2012.

25. Muchiria P. N, Pintelona L, Martinb H, De Meyerc A. M. Empirical analysis of maintenance performance measurement in Belgian industries. International Journal of Production Research 2010; 20, http://dx.doi.org/10.1080/00207540903160766.

26. Nowicki R., Bate M. Inteligentne podejście w rozpoznawaniu anomalii pracy maszyn napędzanych silnikami elektrycznymi. Zeszyty Problemowe - Maszyny Elektryczne 2013; 2.

27. Osińska M. Ekonometria finansowa. Warszawa: PWE, 2006.

28. Perron P. The great crash, the oil price shock, and the unit root hypoth esis. Econometrica 1989; 6: 1361-1401, http://dx.doi. org/10.2307/1913712.

29. Polska Norma PN-EN 15341:2007 - Maintenance - Maintenance Key Performance Indicators. Warszawa: Polski Komitet Normalizacyjny, 2007.

30. Simões J.M, Gomes C.F, Yasin M.M. A literature review of maintenance performance measurement: A conceptual framework and directions for future research. Journal of Quality in Maintenance Engineering 2011; 2(17), http://dx.doi.org/10.1108/13552511111134565.

31. Sobieski W. Stanowisko laboratoryjne do badania zjawiska kawitacji metodą wibroakustyczną. Diagnostyka 2004; 32 : 37-42.

32. Srivastava N.K., Mondal S. Development of a Predictive Maintenance Model Using Modified FMEA Approach. IUP Journal of Operations Management 2014; : 7-16.

33. Tabakow M., Korczak J., Franczyk B. Big Data - definicje, wyzwania i technologie informatyczne. Informatyka Ekonomiczna = Business Informatics 2014; 1 .

34. Uhl T., Barszcz T. Informatyczne aspekty projektowania systemów monitorowania stanu maszyn- sprzęt i oprogramowanie. Diagnostyka 2001; 24.

35. Walczak M. System utrzymania ruchu czynnikiem przewagi konkurencyjnej przedsiębiorstwa// Historia i perspektywy nauk o zarządzaniu. Księga pamiątkowa dla uczczenia jubileuszu 40-lecia pracy naukowo-dydaktycznej prof. zw. dra hab. Arkadiusza Potockiego / Mikuła B. [red]. Kraków: Fundacja Uniwersytetu Ekonomicznego w Krakowie, 2012.

36. Yuan Y., Jiang X., Liu X. Predictive maintenance of shield tunnels. Tunnelling and Underground Space Technology 2013; 38, http://dx.doi. org/10.1016/j.tust.2013.05.004.

37. Żabicki D. Zastosowanie kamer termowizyjnych. Monitorowanie i Diagnostyka 2014; 2: 16-19.

\section{Ewelina KOSICKA \\ Dariusz MAZURKIEWICZ}

Mechanical Engineering Faculty

Lublin University of Technology

ul. Nadbystrzycka 36, 20-618 Lublin, Poland

\section{Edward KOZŁOWSKI}

Faculty of Management

Lublin University of Technology

ul. Nadbystrzycka 38, 20-618 Lublin, Poland

E-mail: e.kosicka@pollub.pl, d.mazurkiewicz@pollub.pl e.kozlovski@pollub.pl 